\title{
ОСОБЛИВОСТІ ОРГАНІЗАЦІЇ САМОСТІЙНОЇ РОБОТИ ІНОЗЕМНИХ СТУДЕНТІВ В КОНТЕКСТІ КРЕДИТНО-МОДУЛЬНОЇ СИСТЕМИ ПРИ ВИВЧЕННІ ФАРМАЦЕВТИЧНОЇ ХІМІЇ
}

Л. М. Мосула

ДВНЗ “Тернопільський державний медичний університет імені І. Я. Горбачевського МОЗ Украӥни”

\author{
FEATURES OF ORGANIZATION OF INDEPENDENT WORK OF \\ FOREIGN STUDENTS IN THE CONTEXT OF CREDIT-MODULAR \\ SYSTEM AT STUDYING OF PHARMACEUTICAL CHEMISTRY
}

\author{
L. M. Mosula \\ SHEI "Ternopil State Medical University by I. Ya. Horbachevsky of MPH of Ukraine”
}

\begin{abstract}
Стаття присвячена деяким питанням організації самостійної роботи іноземних студентів при вивченні фармацевтичної хімії згідно з вимогами кредитно-модульної системи навчання. Відзначено, що саме добре продумана і педагогічно доцільно організована самостійна робота стимулює студентів до систематичної праці протягом семестру, навчального року та періоду професійного навчання.
\end{abstract}

The article is devoted to some points of organization of independent work of foreign students at the study of pharmaceutical chemistry according to the requirements of credit-modular system of studies. It is marked that carefully thought out and pedagogically organized independent work stimulates students to the systematic activities during the semester, academic year and the period of professional studies.

Вступ. 3 метою забезпечення якості вищої освіти України та ії інтеграції в європейське і світове освітнє співтовариство, відповідно до наказу МОН України № 943 від 16.10.2009 [1], у вищих навчальних закладах України було запроваджено Європейську кредитно-трансферну систему (ECTS), не став винятком i наш університет. Основою ECTS є кредитно-модульна система організації навчального процесу, яка передбачає реорганізацію традиційної схеми “навчальний семестр - навчальний рік - навчальний курс", раціональний поділ навчального матеріалу дисципліни на модулі й перевірку якості засвоєння теоретичного і практичного матеріалу кожного модуля, використання ширшої шкали оцінювання знань, вирішальний вплив суми балів, одержаних упродовж семестру, на підсумкову оцінку [2, 3]. Завдання кожного викладача в умовах кредитно-модульної системи навчання не навчити студента, а навчити його вчитися, тобто самостійно оволодівати знаннями, вміннями і практичними навичками, передусім закласти в нього i усіляко підтримувати бажання стати професіоналом у своій галузі. При дотриманні паритетних взаємин викладачі контролюють успішність студента, використовуючи методи і засоби, що їх визначає вищий навчальний заклад [4]. Вважається, що при введенні ECTS полегшується академічне визнання дипломів і кваліфікацій, стають прозорими освітні програми і навчальні плани, що робить вищу освіту України більш привабливою для студентів з різних країн. Усі ці зміни вимагають певних реформ в організації навчального процесу.

Основна частина. Концепція розвитку Тернопільського державного медичного університету імені I. Я. Горбачевського [5] передбачає забезпечення мобільності студентів у Світовому освітньому просторі і впровадження принципів кредитно-модульної системи навчання в організацію навчального процесу, що приваблює не лише вітчизняних студентів, а й студентів з інших країн світу. 3 року в рік кількість іноземних студентів (більшість 3 яких англомовні) збільшується в нашому університеті та на фармацевтичному факультеті зокрема. Викладання фармацевтичної хімії іноземним студентам англійською мовою на кафедрі фармацевтичної хімії ведеться 3 2009 року, хоча донедавна проводилось виключно російською. Це, в свою чергу, підвищує вимоги до рівня мовної підготовки англомовних викладачів та вимагає збільшення їх кількості. Колектив кафедри

() Л. М. Мосула 
постійно готує резерв з молодих викладачів, аспірантів, магістрів.

Незаперечним цінним здобутком реформування системи навчання у нашому університеті є впровадження Z-системи навчання, що передбачає забезпечення поступового переходу від теорії до практики, впритул наближаючи студентів до рівня вимог, необхідних для майбутньої професії, що ще більше стимулює їх до самовдосконалення. Оптимізації навчання іноземних студентів сприяє також впровадження у навчальний процес методики “єдиного дня”, оскільки вона дозволяє їм зосередити свої зусилля на вивченні протягом заняття, яке триває 6 або 7 академічних годин, однієї дисципліни [6].

Згідно 3 новими освітніми стандартами значно підвищується роль самостійної робити студентів (СРC) у професійній підготовці, адже сучасному суспільству необхідні фахівці, здатні оперативно приймати рішення, діяти творчо, самостійно. В даних умовах завдання викладачів - добре продумати i методично правильно організувати СРС. Запорукою ефективної організації СРС є розробка науково-методичного супроводу та організаційно-методичного забезпечення індивідуальної роботи студентів, що є провідною метою діяльності кафедри. В умовах скорочення аудиторних годин за рахунок збілышення часу на СРС відбувається переорієнтація процесу навчання з лекційно-інформативної на індивідуально-диференційовану, особистісно-орієнтовану форми [3, 4]. Самостійна робота умовно поділяється на аудиторну і позааудиторну, а час, відведений для неї, регламентується навчальним планом.

Для якісної підготовки студентів до занять у нашому ВНЗ створені усі умови: функціонує сучасна загальна університетська бібліотека з читальною залою, ряд комп'ютерних класів, приєднаних до мережі Інтернет та Інтранет, активна і доступна для всіх студентів потужна база електронних навчальних матеріалів, розміщених на WEB-порталі університету та WEB-сторінці кафедри зокрема; з'явилась також можливість використання WiFi-доступу, чим широко користуються іноземні студенти, які мають портативні комп'ютери. Оскільки на даний час немає універсального підручника 3 фармацевтичної хімії англійською мовою, який би в доступній і обгрунтованій формі подав хімічну тематику з врахуванням основних питань типової програми, розробленої за кредитно-модульною системою навчання, викладачами кафедри підготовлені матеріали підготовки до практичних робіт та лекцій (текстовий матеріал, малюнки, таблиці, схеми тощо), презентації лекцій, які постійно оновлюються і доповнюються новою інформацією, навчальні відеоролики, що розміщуються на WEB-сторінці кафедри. Розроблені і випущені друкарським способом методичні рекомендації англійською мовою до практичних занять 3 фармацевтичної хімії, а також робочий зошит для протоколів практичних занять, де студенти записують рівняння реакцій, проводять необхідні розрахунки, роблять висновки щодо якісного та кількісного вмісту субстанцій лікарських речовин, їх відповідності вимогам Фармакопеї чи іншим методам контролю якості (МКЯ). Це значно економить їх час у підготовці до занять i звільняє його для самовдосконалення і самоосвіти.

Взаємодія педагога та студента в навчальному процесі відбувається на принципово новій основі: за допомогою модулів, при цьому студенти більше часу працюють самостійно, вчаться досягати мети, планувати і оцінювати свою діяльність. СРС над змістовим модулем з фармацевтичної хімії передбачає виконання різних видів завдань (репродуктивних, за зразком, реконструктивно-варіативних, частковопошукових, навчально-дослідних), спрямованих на отримання студентом нових знань, їх систематизацію та узагальнення; формування практичних вмінь та навичок; контроль готовності студента до лекцій, практичних занять, захисту практичних робіт, інших контрольних заходів. При вивченні фармацевтичної хімії усіляким чином стимулюється і підтримується СРС, що полягає у:

- пошуку матеріалу до певної теми і тезисному конспектуванні важливих питань;

- опрацюванні теоретичних основ прослуханого лекційного матеріалу з використанням тезисного конспектування лекцій, посібника, пропонованої літератури;

- підготовці додаткового матеріалу до лекцій відповідно до заданого плану;

- вивченні окремих тем або питань, що передбачені для самостійного опрацювання $з$ метою реферування, анотування, складання тезисного плану, конспекту тощо;

- аналізі, синтезі, порівнянні, узагальненні інформації з заданої тематики з метою підготовки відповідей на питання самоконтролю;

- розв'язуванні ситуаційних задач різного рівня складності та тестових завдань для вихідного, рубіжного і заключного контролю;

- електронному тестуванні напередодні заняття за системою "Moodle", виконанні домашніх завдань;

- підготовці до проведення, виконанні та захисті практичних робіт, в результаті яких студенти набу- 
вають потрібних для майбутньої професії практичних навичок і вмінь;

- підготовці рефератів з метою поглибленого вивчення того чи іншого питання;

- підготовці до проведення контрольних заходів (складання змістових модулів, написання модульних контрольних робіт, іспитів тощо);

- написанні та захисті курсових робіт;

- оформленні звітів за результатами практик;

- роботі з пошуковими системами Інтернет, зокрема, пошуку та аналізі електронних підручників і посібників, навчальних відеофільмів 3 предмета тощо.

Самостійна робота студента над засвоєнням навчального матеріалу з фармацевтичної хімії може виконуватися у бібліотеці, комп'ютерних класах, навчальних кабінетах і лабораторіях кафедри, а також у домашніх умовах. Якщо при самонавчанні у студентів виникають труднощі, вони можуть скориста- тися консультацією чергового викладача з предмета в спеціально відведені для цього дні.

Висновки: 1. Без сумніву, специфіка майбутньої професії потребує від студентів систематичної самостійної роботи, безперервного самовдосконалення, а педагогічно доцільно організована викладачами СРС спонукає їх до цього.

2. При роботі з іноземними студентами важливим $\epsilon$ використання принципу багаторівневості, що дозволяє в повному обсязі врахувати індивідуальні можливості студентів, рівень їхнього актуального розумового розвитку, ступінь оволодіння навчальним матеріалом.

3. Лише співробітництво викладачів і студентів у процесі організації самостійної роботи створює сприятливі умови для педагогічного стимулювання навчання, посилення ролі самооцінки, ділових взаємовідносин, що значно наближає нас до сучасних зразків організації навчання в університетах розвинутих країн Заходу.

\section{Лiтература}

1. Про запровадження у вищих навчальних закладах України Свропейської кредитно-трансферної системи : наказ МОН України №943 від 16.10.2009.

2. Баркалова Е. Л. Організація навчального процесу в контексті впровадження кредитно-модульної технології / Е. Л. Баркалова // Медична освіта. -2007. -№4.-С. 13-15.

3. Підготовка висококваліфікованого спеціаліста-основа впровадження кредитно-модульної системи навчання / Л. Ф. Каськова, О. О. Карпенко, О. Е. Абрамова [та ін.] // Медична освіта. -2011.-№ 3. - С. 82-84.

4. Москаленко В. Ф. Про стан і шляхи удосконалення

організації СРС / В. Ф. Москаленко, О. П. Яворівський, Л. І. Остапик // Медична освіта. - 2004. - № 1. - С. 10-12.

5. Концепція розвитку Тернопільського державного медичного університету імені І. Я. Горбачевського (інтеграція у світовий медичний освітній простір). - Тернопіль : ТДМУ, 2006. $-50 \mathrm{c}$.

6. Ковальчук Л. Я. Результати реалізації концепції розвитку Тернопільського державного медичного університету імені І. Я. Горбачевського на шляху входження у світовий освітній простір / Л. Я. Ковальчук // Медична освіта. -2011. -№ 2. - C. 12-19. 